\title{
EVALUATION OF SOIL EROSION PROCESS AND CONSERVATION PRACTICES IN THE PARAGOMINAS-PA MUNICIPALITY (BRAZIL)
}

\author{
Denis Conrado da CRUZ ${ }^{1}$, José María Rey BENAYAS ${ }^{1}$, Gracialda Costa FERREIRA ${ }^{2}$, \\ André Luis MONTEIRO ${ }^{3}$, Gustavo SCHWARTZ ${ }^{4}$
}

DOI: $10.21163 / \mathrm{GT} \_2019.141 .02$

\begin{abstract}
:
Over the last decades, the natural environment has been degraded at a much greater speed than its own resilience. Lack of knowledge about soil natural limitations and mismanagement can increase their degradation and nutrient losses by erosion. The objective of this study was to estimate and map soil vulnerability to erosion through the Universal Equation of Revised Soil Loss (RUSLE) and based on the ecodynamic concept of physical and biotic environment analysis, and finally to evaluate conservation practices in the municipality of Paragominas with the economic database of IBGE / SIDRA. In the two analyzed methods the percentage of area with low and high potential and erosivity estimation were similar. The estimation of low and low-moderate loss and vulnerability represents about $77 \%\left(15,064 \mathrm{~km}^{2}\right)$ of the territory by RUSLE and $60 \%\left(11,485 \mathrm{~km}^{2}\right)$, by ecodynamic concept. The high to very high soil loss zones represent only $3 \%\left(642 \mathrm{~km}^{2}\right)$ and $2.7 \%\left(584 \mathrm{~km}^{2}\right)$, in the RUSLE and ecodynamic concept, respectively. Most of the variables analyzed in both methods presented low estimation values of loss and erosivity potential. The soil and slope attributes, for example, obtained exactly $79 \%\left(15,377 \mathrm{~km}^{2}\right.$ - RUSLE) and $80 \%\left(15,572 \mathrm{~km}^{2}\right.$ - ecodynamic concept), except for the climate and factor R attributes, in both methods the vulnerability potential and erosion, were only $1.5 \%\left(292 \mathrm{~km}^{2}\right)$ and $1.3 \%$ $\left(253 \mathrm{~km}^{2}\right)$, based on the ecodynamic concept and RUSLE respectively. The geospatial analysis of the use practices correlated with the economic data showed an intense use of agricultural activities, logging and mining, which caused severe environmental damages, considering that $45 \%\left(8,773.3 \mathrm{~km}^{2}\right)$ of the municipality have already been deforested and converted into other uses. The municipality still has $47 \%\left(9,182 \mathrm{~km}^{2}\right)$ of its territory covered by altered primary vegetation and $23 \%\left(4,441 \mathrm{~km}^{2}\right)$ by secondary vegetation, important information to subsidize decision-making processes related to ecologicaleconomic strategies for the management of natural resources in the study area.
\end{abstract}

Key-words: Agriculture, Environmental variables, Potential for soil loss, Amazon

\section{INTRODUCTION}

Erosion is a process by which soil and rocks wear out, then transported by natural or anthropogenic agents and deposited elsewhere (Verheijen et al., 2009), it can pollute water, cause land degradation, reduce soil fertility and increase the loss of organic matter (Cerdan et al., 2010). Changes in the management and use of land resulted from human activities can increase soil erosion causing irreversible damage to the environment (Fiorio et al.,

\footnotetext{
${ }^{1}$ University of Alcalá, Life Sciences Department, 28871, Alcalá de Henares, Spain, conrado_denis@hotmail.com; josem.rey@uah.es.

${ }^{2}$ Amazon Rural Federal University, 66.077.830, Belém Brazil, gracialdaf@yahoo.com.br.

${ }^{3}$ Geoforest Consultancy, 66063-040,Belém-Pa, Brasil, monteiroandre7@gmail.com.

${ }^{4}$ Forest Ecology and Management Embrapa Eastern Amazon, 70.770.901, Belém, Brazil, gustavo.schwartz@embrapa.br.
} 
2016; Da Silva et al., 2016). The vegetation withdrawal due to the insertion of plantations can increase up to $600 \%$ soil erosion (Chaplot et al., 2005). Soil loss brings concern all over the planet, as it is a source for food production (Abel et al., 2005).

Production of food and other goods for human needs, combined with population growth and agricultural intensification, has resulted in severe land degradation and, particularly, soil erosion. Between 1961 and 2010 the world population duplicated from 3 billion to 6 billion inhabitants, while the crop production increased four time in almost the same area (FAO, 2017). It is estimated that since the beginning of stable agriculture, ca. 430 million hectares was damaged due to soil erosion (Lal, R, 2017).

Agricultural production in Brazil was fostered through a National Development Plan in the 1970s aiming to improve the country economy (Becker, 2005). Such Plan was developed to attract entrepreneurs to the Brazilian Amazon, with the government releasing taxes on rural credits to incentivize investment (Kohlhepp, 2002). That period was marked by huge agricultural, industrial, and silvicultural projects besides infrastructure actions (Hall, 1989; Serra, 1998). The intense advance of the agricultural sector and the territory occupation was evident in many Amazon municipalities, leading to a drastic change in the landscape. For example, Paragominas has already $45 \%\left(8,773.3 \mathrm{~km}^{2}\right)$ of its land deforested (INPE/Prodes, 2018), causing loss of soil organic matter and nutrients and soil erosion (Angima, 2003). Lack of knowledge about soil limitations and inadequate soil management practices can trigger or speed up its erosion in agricultural areas (Navas et al., 2005). Beyond land use activities, soil loss and degradation are affected by a combination of different environmental factors including geology (rock types), geomorphology (landform), vegetation (e.g. its cover and structure), pedology (soil types), and climate (e.g. rainfall) (Arnesen, 2009). The awareness about risks to environment, economy and livelihoods have resulted in research, technology and production practices to minimize soil erosion (Bakker et al., 2008).

Understanding and quantifying erosion processes are important steps in the decision making process regarding the best management to be adopted. Methods with empirical models are used, for example, the Universal Soil Loss Equation (USLE), which emerged in the late 1970s (Wischmeier \& Smith, 1978) in the United States, but it is widely used in Brazil. This method presents great accuracy, as considers soil type, soil morphology, rainfall, cultivation practices and management, allows quantification and regionalization of the area with higher risk of erosion (Wischmeier \& Smith, 1978; Bertoni, 2005; 2012). It was later revised and adapted by several authors "Revised Universal Soil Loss Equation" (RUSLE). Another technique widely used to analyze the natural vulnerability to soil loss was based on the ecodynamic of Tricart (1977), modified by Crepani et al., (2001), which uses the morphogenesis/pedogenesis relation integrated to satellite images, assigning values of vulnerability/stability to each thematic class.

The use of remote sensing and geographic information systems contribute significantly to monitoring, mapping, and managing landscapes (Ferreira, 2008), particularly in large and remote areas. For example, in Brazil where, besides having huge territorial extension, the access to some areas is also a constraint, what emphasizes the need of a constant input in this field in order to monitor effectively (Assad \& Sane, 1998; Câmara et al., 2001). This study aims to estimate and map vulnerability to soil erosion through geospatial analysis, by the model of the Universal Equation of Soil Loss Revised (RUSLE), ecodynamic concept of analysis of physical and biotic environment and conservation practices evaluation in Paragominas municipality in the Brazilian Amazon. We analyzed the local attributes of geology, geomorphology, vegetation, pedology, and climate, by means of satellite imagery 
analysis, thematic maps, and rainfall data, then a map of land was obtained which represents a range of levels of vulnerability to soil erosion. The analysis presented here can contribute to support decision makers regarding ecological-economic strategies for natural resource management in the study area and other parts of Brazilian Amazon.

\section{MATERIAL AND METHODS}

\subsection{Study site}

Paragominas municipality has an area of $19,465 \mathrm{~km}^{2}$ and it is placed in Pará state, Brazil. Its original vegetation was mainly formed by Dense Ombrophilous Forest (Watrin, 1992). The predominant soil type is yellow latosol, rich in clay and has low fertility. The climate is warm and humid, with annual average temperature of $26.3^{\circ} \mathrm{C}$ (Fig. 1).

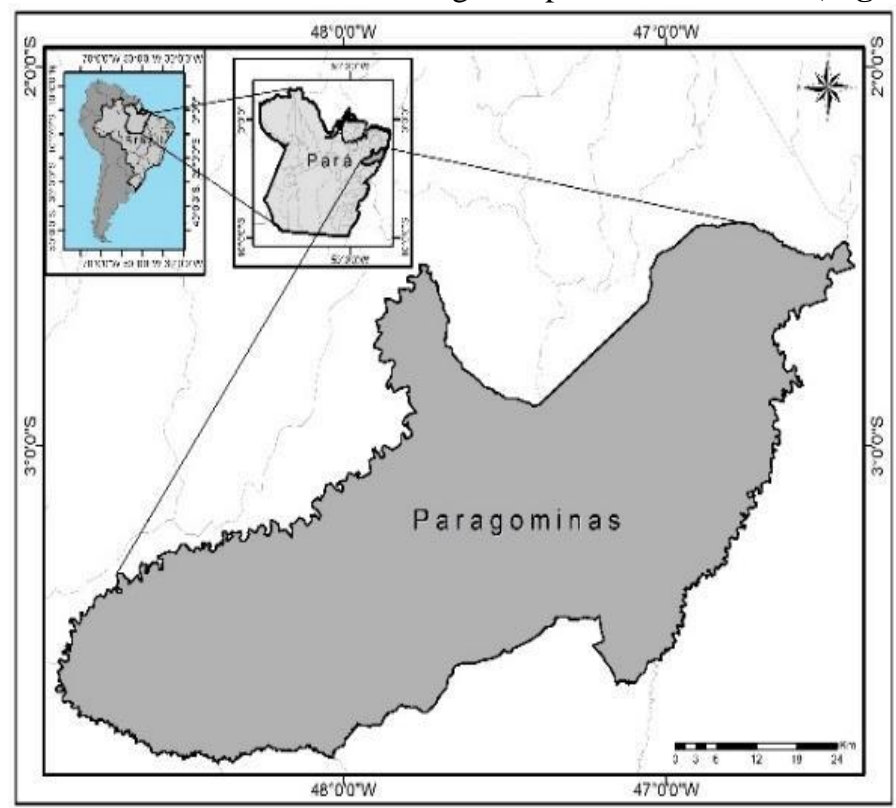

Fig.1. Paragominas municipality (Source: authors).

\subsection{Estimation and mapping of soil erosion}

Soil erosion estimations were carried on the concept proposed by Tricart (1977), adapted by Crepani (2001) and by the Revised Universal Soil Loss Equation - RUSLE (Wischmeier and Smith, 1978). Both methods evaluate soil erosion with variables such as: rainfall; soil type; land-use class; geology and geomorphology.

\subsection{Soil erosion based on the ecodynamic concept}

We used the method based on the ecodynamic concept (Tricart, 1977), adapted by Crepani et al., (2001) to Brazil. This concept considers the balance between soil formation processes (pedogenesis) and erosion processes (morphogenesis). It applies a range of soil erosion vulnerability values to the target land areas that are analyzed (stability or instability). Areas where pedogenesis and morphogenesis predominate have a value around 1 and 3, respectively, and areas where both processes are balanced have values around 2 (Table 1). 
Classes of soil erosion vulnerability.

\begin{tabular}{cc}
\multicolumn{2}{c}{ Classes of soil erosion vulnerability. } \\
\hline Class & Vulnerability Value \\
\hline Low Vulnerability & $1>-1.6$ \\
Low-moderate vulnerability & $1.6-1.9$ \\
Moderate vulnerability & $1.9-2.1$ \\
High-moderate vulnerability & $2.1-2.4$ \\
High vulnerability & $2.4-3$ \\
Source: Elaborated by the author, adapted from Crepani et al., (2001), \\
by ecodynamic concept (Tricart, 1977).
\end{tabular}

Table 1.

Vulnerability values of soil erosion (between 1 and 3) were assigned based on attributes related to geology, geomorphology, pedology, vegetation types, and climate variables. They resulted in five thematic maps obtained by means of the Map Algebra of ArcGis 10.1 (Esri, 2012). For a given land area, the overall vulnerability (V) was:

Where:

$$
V=G+S L+S+V g+C / 5
$$

$\mathrm{G}=$ vulnerability due to Geology, $\mathrm{SL}=$ vulnerability due to Slope, $\mathrm{S}=$ vulnerability due to Soil, $\mathrm{Vg}=$ vulnerability due to Vegetation, and $\mathrm{C}=$ vulnerability due to Climate.

\subsubsection{Geology attribute}

Vulnerability due to Geology depends upon rock type. We used the geological database of the Brazilian Geological Service (CPRM, http://www.cprm.gov.br/), at a 1:100.000 spatial scale. The CPRM provides data in georeferenced vector format of aerogeophysical projects available in Geobank (http://geobank.cprm.gov.br/). Values of soil erosion vulnerability related to rock types in the study area are reported in Table 2.

Values of soil erosion vulnerability related to rock types.

\begin{tabular}{lc}
\hline \multicolumn{1}{c}{ Rock types } & Value \\
\hline Quartzites or metaquartzites & 1.0 \\
Rhyolite, Granite, Dacite & 1.1 \\
Granodiorite, Quartz Diorite, Granulites & 1.2 \\
Migmatite, Gneiss & 1.3 \\
Phonolite, Nepheline syenite, Trachyte, Syenite & 1.4 \\
Andesite, Diorite, Basalt & 1.5 \\
Anorthosite, Gabbro, Peridotite & 1.6 \\
Mylonitos, Muscovite Quartz, Biotite, Shale chlorites & 1.7 \\
Pyroxene, Kimberlite amphibolite, Dunite & 1.8 \\
Hornblende, Tremolite, Shale actinolite & 1.9 \\
Shale Staurolite, Granatiferous shale & 2.0 \\
Phyllite, Metassiltite & 2.1 \\
Slate, Metargilite & 2.2 \\
Marbles & 2.3 \\
Quartz Sandstone or orthoquartzites & 2.4 \\
Conglomerates, Subgraywacke & 2.5 \\
Greywackes, Arkose & 2.6 \\
Siltstones, Mudstones & 2.7 \\
Husk & 2.8 \\
Calcareous, Dolomites, Marls, Evaporites & 2.9 \\
Soft-bottom sediments: Alluvium, Colluvium, Sands, etc. & 3.0 \\
\hline
\end{tabular}

Source: Elaborated by the author, adapted from Crepani et al., (2001), by ecodynamic concept. 


\subsubsection{Slope attribute}

The source of soil erosion vulnerability related to slope, was adapted by Crepani et al., (2001) study (Table 3). These data derive from SRTM (Shuttle Radar Topography Mission) available on EMBRAPA (Brazilian Corporation of Agricultural Research, (https://www.embrapa.br/territorial/), calculated using the ArcGis 10.1 Solpe tool.

Values of soil erosion vulnerability related to slope.

Table 3.

\begin{tabular}{|c|c|c|c|c|c|c|c|c|}
\hline $\begin{array}{c}\text { Degre } \\
\mathrm{e}\end{array}$ & $\%$ & $\begin{array}{c}\text { Value/ } \\
\text { Vuln. }\end{array}$ & Degree & $\%$ & $\begin{array}{c}\text { Value/ } \\
\text { Vuln. }\end{array}$ & Degree & $\%$ & $\begin{array}{c}\text { Value/ } \\
\text { Vuln. }\end{array}$ \\
\hline$<2$ & $<3.5$ & 1.0 & $9.9-11.2$ & $17.4-19.8$ & 1.7 & $19.1-20.4$ & $34.6-37.2$ & 2.4 \\
\hline $2-3.3$ & $3.5-5.8$ & 1.1 & $11.2-12.5$ & $19.8-22.2$ & 1.8 & $20.4-21.7$ & $37.2-39.8$ & 2.5 \\
\hline $3.3-4.6$ & $5.8-8.2$ & 1.2 & $12.5-13.8$ & $22.2-24.5$ & 1.9 & $21.7-23.0$ & $39.8-42.4$ & 2.6 \\
\hline $4.6-5.9$ & $8.2-10.3$ & 1.3 & $13.8-15.2$ & $24.5-27.2$ & 2.0 & $23.0-24.4$ & $42.4-45.3$ & 2.7 \\
\hline $5.9-7.3$ & $10.3-12.9$ & 1.4 & $15.2-16.5$ & $27.2-29.6$ & 2.1 & $24.4-25.7$ & $45.3-48.1$ & 2.8 \\
\hline $7.3-8.6$ & $12.9-15.1$ & 1.5 & $16.5-17.8$ & $29.6-32.1$ & 2.2 & $25.7-27$ & $48.1-50$ & 2.9 \\
\hline $8.6-9.9$ & $15.1-17.4$ & 1.6 & $17.8-19.1$ & $32.1-34.6$ & 2.3 & $>27$ & $>50$ & 3.0 \\
\hline
\end{tabular}

Source: Elaborated by the author, adapted from Crepani et al., (2001), by ecodynamic concept.

\subsubsection{Pedology attribute}

The vulnerability related to the pedology attribute (Table 4) refers to mapping of soil units according to Crepani et al., (2001), updated with Prado (2001) nomenclature. This attribute database was obtained from IBGE (Brazilian Institute of Geography and Statistics), based on the new Brazilian System of Soil Classification (EMBRAPA, 1999).

Soil erosion vulnerability values related to soil types.

\begin{tabular}{cccc}
\hline Soil Classes & Vuln. & Soil classes & Vuln. \\
\hline Yellow Latosol & 1 & Spodosol & 2 \\
Red-Yellow Latosol & 1 & Neosol Litólicos & 3 \\
Red Latosol & 1 & Neossolos Flúvicos & 3 \\
Latosol Brunos & 1 & Neossolos Regolíticos & 3 \\
Latosol (...) Humic & 1 & Neossolos Quartzarênicos & 3 \\
Latosol Bruno (...) Humic & 1 & Vertisol & 3 \\
Acrisol & 2 & Organosols & 3 \\
Acrisol Luvisol Alisol Nitosol & 2 & Gleysol & 3 \\
Acrisol Nitosol & 2 & Gleysols Plinthosol & 3 \\
Luvisol & 2 & Plinthosol & 3 \\
Chernozem & 2 & Rocky Outcrop & 3 \\
Planosol & 2 & - & -
\end{tabular}

Source: Elaborated by the author, adapted from Crepani et al., (2001), with new nomenclature from Prado (2001).

\subsubsection{Vegetation and use of class attribute}

The definition of values on vulnerability to erosion regarding vegetation attribute was identified under the forest canopy density using satellite imagery determined 21 class units, following the Crepani et al., (2001) definition (Table 5).

It was used satellite imagery from Landsat $8 \mathrm{TM}$, orbits/points 222/62, 222/63, 223/62, and 223/63 (2015 data), with the lowest cloud coverage of the period, available in the website Glovis from NASA. From these satellite imageries were produced a classification using the supervised Maximum Likelihood method. This method uses mean and variance of the data set for the classification decision rule and for this reason a considerable number of pixels is required for each region to be classified. First the use class was defined, then 
samples (ROI's) of the areas to be classified in the image were generated (Table 6). With the selected ROI's for use class the image was classified using the software ENVI 4.7, afterward vulnerability values of classes were set as follows in Table 7 .

Table 5.

Soil erosion vulnerability values related to vegetation types.

\begin{tabular}{lc}
\hline Vegetation Class & Vuln. \\
\hline Dense Ombrophilous Forest & 1.0 \\
Open Ombrophilous Forest & 1.0 \\
Mixed Ombrophilous Forest & 1.0 \\
Semideciduous Seasonal Forest & $1.4-1.7$ \\
Campinaranas formation & $1.4-1.7$ \\
Forested Savanna and Steppe Savanna & $1.4-1.7$ \\
Dense tree steppe, with or without palms & $1.4-1.7$ \\
Wooded Savanna and Steppe Savanna da e Wooded Steppe Savanna & 2.0 \\
Decidual Seasonal Forest & 2.0 \\
Wooded Campinarana & 2.0 \\
Wooded Steppe & 2.0 \\
Buritizal with fluvial and/ or lake influence & 2.0 \\
Wooded Campinarana with or without palms & $2.4-2.6$ \\
Savanna Park, Wooded Savanna Park & $2.4-2.6$ \\
Campinarana and Steppe with shrub size & $2.4-2.6$ \\
Vegetation under marine influence (Sandbanks) & $2.4-2.6$ \\
Vegetation under fluvial and/or lake influence & $2.4-2.6$ \\
Montane Refuge and High Montane Refuge & $2.4-26$ \\
Woody- grassy Savanna, Woody-grassy steppe savanna, and Woody- & 3.0 \\
grassy steppe & \\
Woody-grassy campinarana & 3.0 \\
Vegetation under herbaceous marine influence & 3.0 \\
Montano and High-Montano refuges & 3.0 \\
Cloud/ Shadow/ exposed soil/ sparse vegetation & 3.0 \\
\hline
\end{tabular}

Source: Elaborated by the author, adapted from Crepani et al., (2001), by ecodynamic concept.

\subsubsection{Climate attribute}

About the attribute climate (pluviometry), 21 classes were classified on soil erosion (Table 8). The areas with lower annual pluviometric rate and higher extension of rainy season were classified with values around stability (1.0) to intermediary values of vulnerability/stability (2.0). On the other hand, areas with higher annual pluviosity rate and shorter rainy season vulnerability presented values around 3.0. In order to assign the vulnerability values to the climate, the precipitation data of the last 18 years of the municipality station, was used in the system of the national meteorological institute (INMET-http://www.inmet.gov.br/portal/). The average precipitation was calculated between the months of January 2000 and November 2018 (Fig. 2).

\subsection{Revised Universal Soil Loss Equation (RUSLE) method.}

Through the RUSLE equation, the main spatial distribution factors responsible for soil erosion were performed in the GIS environment. Information plans were embedded into the database and manipulated through the geoprocessing tools in ArcGis (Fig. 3). 
Table 6.

Land use patterns and Vegetal cover used in the satellite image classification.

\begin{tabular}{|c|l|l|}
\hline $\begin{array}{c}\text { Typological } \\
\text { classification }\end{array}$ & $\begin{array}{c}\text { Pattern identified in } \\
\text { satellite image }\end{array}$ & \multicolumn{1}{|c|}{ Description } \\
\hline Primary Forest & & $\begin{array}{l}\text { Forests that have passed through interventions in the } \\
\text { past, but have their primary structure conserved. }\end{array}$ \\
\hline Secondary Forest & $\begin{array}{l}\text { Forests that have undergone deforestation or } \\
\text { degradation processes and are currently in } \\
\text { regeneration. }\end{array}$ \\
\hline Pgriculture & $\begin{array}{l}\text { Livestock pasture areas with low biomass, } \\
\text { characterized areas with healthy pastures and } \\
\text { degraded pastures. }\end{array}$ \\
\hline Deforestation & $\begin{array}{l}\text { Agricultural plantations mechanized, which } \\
\text { presupposes high technological level and family } \\
\text { agriculture areas. }\end{array}$ \\
\hline Urban area & $\begin{array}{l}\text { Areas in which all vegetation cover was removed, } \\
\text { leaving the soil exposed. }\end{array}$ \\
\hline Hydrography & Areas of urban agglomeration, with industrial estates, \\
\hline
\end{tabular}

Source: Elaborated by the author.

Soil Vulnerability regarding vegetation.

Table 7.

\begin{tabular}{|c|c|c|c|c|c|c|c|c|}
\hline \multirow{2}{*}{$\begin{array}{c}\text { LANDSCAPE } \\
\text { UNITES }\end{array}$} & \multirow{2}{*}{\multicolumn{3}{|c|}{ AVERAGE }} & \multirow{2}{*}{ DEGREE OF VULNERABILITY } & \multicolumn{4}{|c|}{ DEGREE OF SATURATION } \\
\hline & & & & & RED & GREEN & BLUE & COLORS \\
\hline U1 & $\uparrow$ & 3.0 & 1 & \multirow{5}{*}{ VULNERABLE } & 255 & 0 & 0 & \\
\hline $\mathrm{U} 2$ & & 2.9 & & & 255 & 51 & 0 & \\
\hline U3 & & 28 & & & 255 & 102 & 0 & \\
\hline $\mathrm{U} 4$ & I & 2.7 & & & 255 & 153 & 0 & \\
\hline U5 & $\mathrm{V}$ & 2.6 & & & 255 & 204 & 0 & \\
\hline U6 & $\mathrm{U}$ & 2.5 & \multirow{4}{*}{$\begin{array}{l}\frac{T}{\mathrm{~S}} \\
\mathrm{~T} \\
\mathrm{~A}\end{array}$} & \multirow{4}{*}{ MODERATE VULNERABILITY } & 255 & 255 & 0 & \\
\hline U7 & $\mathrm{L}$ & 2.4 & & & 204 & 255 & 0 & \\
\hline U8 & $\mathrm{N}$ & 2.3 & & & 153 & 255 & 0 & \\
\hline U9 & E & 2.2 & & & 102 & 255 & 0 & \\
\hline U10 & $\mathrm{R}$ & 2.1 & $B$ & \multirow{5}{*}{$\begin{array}{l}\text { MEDIUM STABLE } \\
\text { VULNERABILITY }\end{array}$} & 51 & 255 & 0 & \\
\hline U11 & $\mathrm{A}$ & 2.0 & $\mathrm{I}$ & & 0 & 255 & 0 & \\
\hline U12 & $B$ & 1.9 & $\mathrm{~L}$ & & 0 & 255 & 51 & \\
\hline U13 & $\mathrm{I}$ & 1.8 & $\mathrm{I}$ & & 0 & 255 & 102 & \\
\hline U14 & $\mathrm{L}$ & 1.7 & $\mathrm{~T}$ & & 0 & 255 & 153 & \\
\hline U15 & $\mathrm{I}$ & 1.6 & $\mathrm{Y}$ & \multirow{4}{*}{ MODERATE STABLE } & 0 & 255 & 204 & \\
\hline U16 & $\mathrm{T}$ & 1.5 & $H$ & & 0 & 255 & 255 & \\
\hline U17 & $\mathrm{Y}$ & 1.4 & & & 0 & 204 & 255 & \\
\hline U18 & 1 & 1.3 & & & 0 & 153 & 255 & \\
\hline U19 & & 1.2 & & \multirow{3}{*}{ STABLE } & 0 & 102 & 255 & \\
\hline $\mathrm{U} 20$ & & 1.1 & & & 0 & 51 & 255 & \\
\hline U21 & 1 & 1.0 & $\downarrow$ & & 0 & 0 & 255 & \\
\hline
\end{tabular}

Source: Elaborated by the author adapted from Crepani et al., (2001), by ecodynamic concept. 
Table 8

Soil vulnerability regarding pluviometric rate.

\begin{tabular}{cccccc}
\hline $\begin{array}{c}\text { Pluviometric } \\
\text { Intensity } \\
\text { mm/month }\end{array}$ & Vuln. & $\begin{array}{c}\text { Pluviometric } \\
\text { Intensity } \\
\text { mm/month }\end{array}$ & Vuln. & $\begin{array}{c}\text { Pluviometric } \\
\text { Intensity } \\
\text { mm/month }\end{array}$ & Vuln. \\
\hline$<050$ & 1.0 & $200-225$ & 1.7 & $375-400$ & 2.4 \\
$50-75$ & 1.1 & $225-250$ & 1.8 & $400-425$ & 2.5 \\
$75-100$ & 1.2 & $250-275$ & 1.9 & $425-450$ & 2.6 \\
$100-125$ & 1.3 & $275-300$ & 2.0 & $450-475$ & 2.7 \\
$125-150$ & 1.4 & $300-325$ & 2.1 & $475-500$ & 2.8 \\
$150-175$ & 1.5 & $325-350$ & 2.2 & $500-525$ & 2.9 \\
$175-200$ & 1.6 & $350-375$ & 2.3 & $>525$ & 3.0 \\
\hline
\end{tabular}

Source: Elaborated by the author adapted from Crepani et al., (2001), by ecodynamic concept.

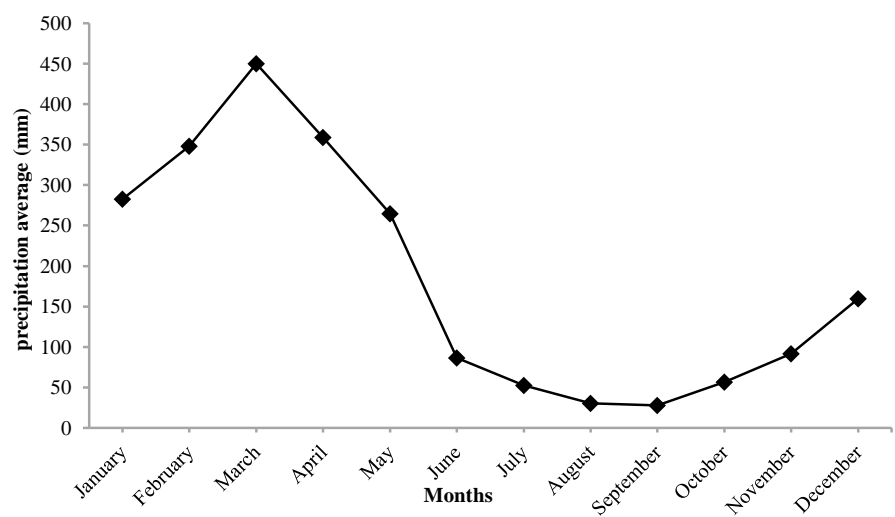

Fig. 2. Precipitation average from 2000 to 2018, INMET data. (source: authors).

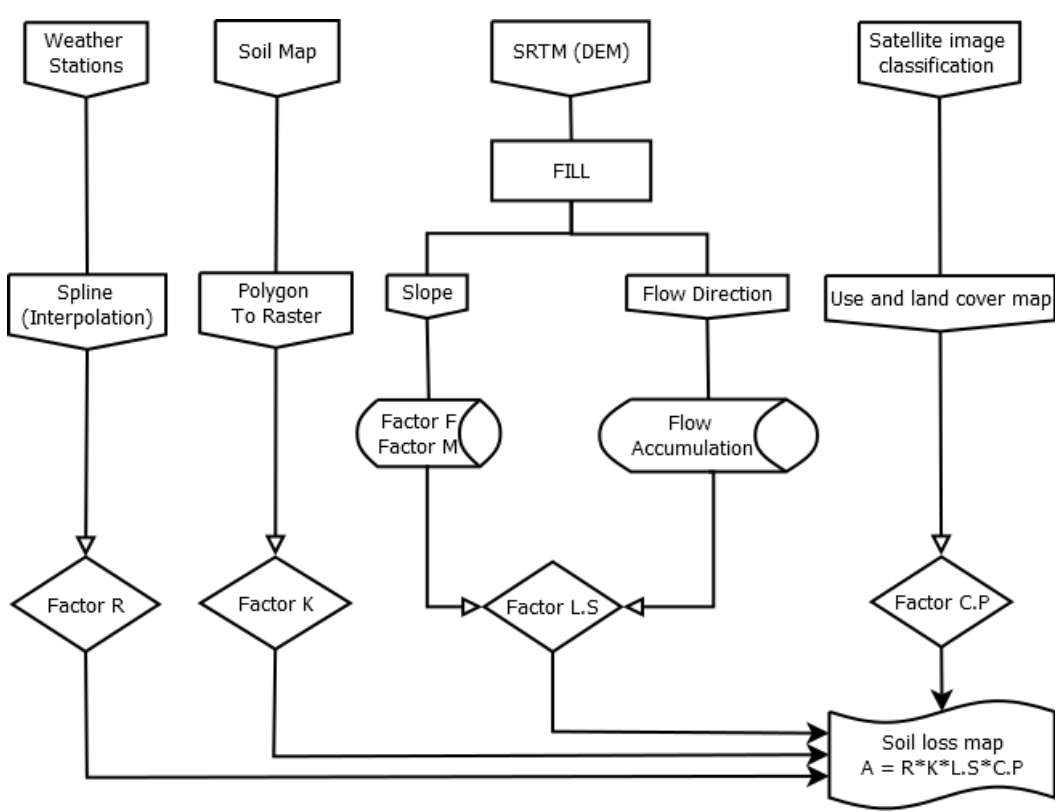

Fig. 3. Flowchart of the technique used in the generation of the soil loss map (source: authors). 


$$
A=R x K x L . S x C \cdot P
$$

Being: $\mathrm{A}=$ Soil loss calculated per unit area, $\left(\mathrm{Mg}_{\mathrm{g}} \mathrm{ha}^{-1} \cdot \mathrm{ano}^{-1}\right) ; \mathrm{R}=$ Rainfall factor: rainfall erosion index, $\left(\mathrm{Mg}_{\mathrm{ha}} \mathrm{a}^{1}\right.$.ano $\left.{ }^{1}\right) ; \mathrm{K}=$ soil erodibility factor $(\mathrm{MJ} / \mathrm{ha} \cdot \mathrm{mm} / \mathrm{h}) ; \mathrm{L}=$ slope length factor, (m); $\mathrm{S}=$ Slope degree factor, $(\%) ; \mathrm{C}=$ Use and management factor (dimensionless); $\mathrm{P}=$ Conservationist practice factor (dimensionless).

\subsubsection{Factor $R$ (Erosivity by rains)}

In order to determine the annual rainfall erosivity, annual average precipitation data of the 28 rainfall stations contained in Paragominas were used for the period from 2000 to 2018. Fig. 2 shows the monthly average rainfall erosivity using the formula used in Amazon:

$$
E I_{\text {monthly }}=42,307\left(\mathrm{Pm}^{2} / \mathrm{Pa}\right)+42,77
$$

Where: $\mathrm{Pm}=$ monthly precipitation and $\mathrm{Pa}=$ annual precipitation average.

The average annual rainfall erosivity is obtained by the sum of the monthly erosivity average of each season. The map was generated in the ArcGis environment, by inserting the table (dbase format) with spatial distribution of the stations (UTM coordinates of the stations) and their respective values of calculated erosivity. The interpolation of the values representing the spatial variation of erosivity was done through the ArcGis Spline tool.

\subsubsection{Factor $\mathrm{K}$ (Soil Erodibility)}

The evaluation of soil erodibility was obtained from IBGE Geoscience Center (Brazilian Institute of Geography and Statistics) in scale 1:5000.000, based on the new Brazilian System of Soil Classification (EMBRAPA, 1999). The soil classes were grouped, generating a map of soil types, where the value of $\mathrm{K}$ was associated for each type.

\subsubsection{Factor LS (Topographic factor)}

In this factor the length of slope $\mathrm{L}$ represents the distance between the point which originates the surface flow to the point where the slope decreases enough for sediment deposition to occur. The slope gradient $(S)$ refers to slope variation in slope intervals, these two parameters (LS) are represented as a single topographic factor, defined as the rate of soil loss per unit area of a standard plot of $22.13 \mathrm{~m}$ in length and $9 \%$ of slope (Wischmeier and Smith, 1978). Calculated by means of the following steps:

$$
\begin{gathered}
F=\frac{\sin \beta / 0.0896}{3(\sin \beta)^{0.8}+0.56} \quad m=\frac{F}{(1+F)} \\
S_{(i, j)}=\left\{\begin{array}{cc}
10,8 \sin \beta(i, j)+0,03 & \tan \beta(i, j)<0,09 \\
16,8 \sin \beta(i, j)+0,5 & \tan \beta(i, j)<0,09
\end{array}\right.
\end{gathered}
$$

In factor $L$ the $\lambda$ is the slope length, $m$ the slope length exponent and $\beta$ the slope angle. The slope length is defined as the horizontal distance from which originates the surface flow to the point where the deposition begins or where the flow flows into a channel, and at factor $S$ the angle $\beta$ is taken as the mean angle of all sub -redes in the steepest direction (Fig. 4). 


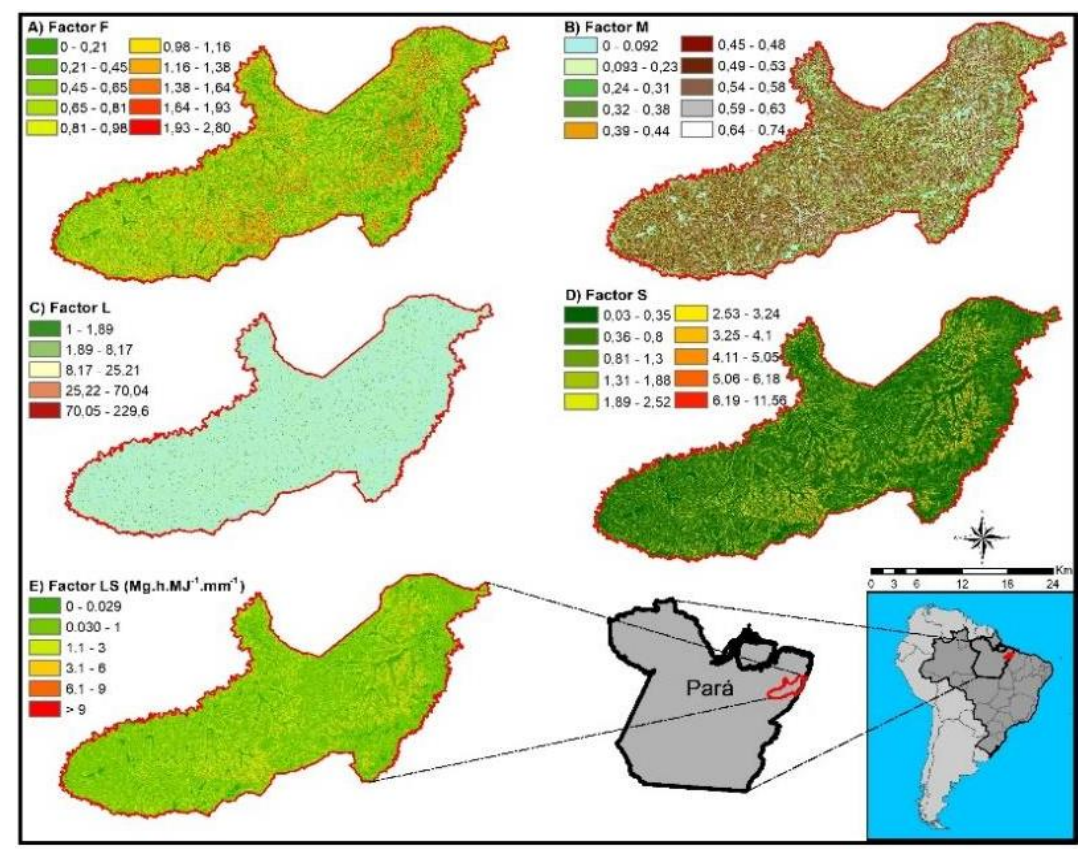

Fig. 4. Erosivity factors for the L.S calculation (source: authors).

\subsubsection{Factor $C$ (Use/soil management) and $P$ (Conservationists practices)}

Factor $\mathrm{C}$ is the expected relationship between the soil loss of a cultivated land under given conditions and the corresponding losses of a land kept continuously uncovered and cultivated (Bertoni, 2005). While the factor $\mathrm{P}$ is the relationship between losses in soils with a given conservationist practice and those where the crop is planted in the slope direction. A factor $\mathrm{P}$ of 0.01 was considered for areas with primary, secondary and urban vegetation, 0.09 for agriculture, 0.45 for pasture, 1 for deforestation and 0 for water. To elaborate the map of factor $\mathrm{C}$, it was necessary to classify the satellite image for soil use and to assign $\mathrm{C}$ and $\mathrm{P}$ values for each type of use (Donzelli et al., 1992), then convert to a raster format, where $\mathrm{CP}=\mathrm{C} . \mathrm{P}$ and $\mathrm{CP}$ factor specializations were obtained from the numerical reclassification of the vegetation cover and land use maps (Table 1) for the year 2017.

\subsection{Conservation management and Practices}

In order to evaluate the activities developed in Paragominas, a mapping was carried out on the land use, a classification carried out by the TerraClass Project, then developed and executed by the Regional Center of the Amazon (CRA). The data base of this project are the mapped deforested areas published by the PRODES Project - Monitoring of the Amazon Forest by Satellite. TerraClass analyzes the possible causes of tree cutting considering the following classes: annual agriculture; unobserved area; urban area; mining; occupation mosaic; pasture with soil exposed; clean pasture; dirty grass; regeneration with grass; reforestation; secondary vegetation; forest and not forest. This mapping counts a series of 10 years analysis of use and coverage (2004, 2008, 2010, 2012 and 2014), and to evaluate the current situation an unsupervised classification was performed in an image from 2017, described in Table 6. 
In order to analyze the use and coverage of the soil obtained by the classifications carried out by satellite images, we also used the data base of the IBGE Automatic Recovery System - SIDRA. This system has an economic historical series of data since 1974, in this component we analyzed only the years of 2004, 2008, 2010, 2012, 2014 and 2017. Another important practice developed in Paragominas is mining and to evaluate this component, it was used data from the National Department of Mineral Production (DNPM), available through the Geographic Information System of Mining - SIGMINE.

\section{RESULTS AND DISCUSSIONS}

After analysis, for the entire area of Paragominas municipality, a map with values of vulnerability to soil erosion was obtained for each following category: geology, slope, pedology, vegetation and climate. Then, a general map of vulnerability to soil erosion and estimates of soil loss was created, according to the method of ecodynamics proposed by Tricart (1977) and adapted by Crepani et al., (2001), and by RUSLE.

\subsection{Analysis of the vulnerability based on the ecodynamic concept}

\subsubsection{Geology attribute}

The basic information of geology is the cohesion degree of integrated rocks from the ecodynamics (Tricart, 1977). It means that in the most cohesive rocks the processes of weathering and pedogenic formation prevailed, while the less cohesive rocks are more susceptible to erosive processes. It is considered that in rocks with little cohesion erosive processes can prevail, while in very cohesive rocks the processes of weathering and soil formation must prevail (Crepani et al., 2001). For this attribute, it was identified that only $1 \%\left(212 \mathrm{~km}^{2}\right)$ of the municipality area has low vulnerability to erosion, with rocks of granite, granodiorite, gneiss and schist, with value between 1.1 to 1.3 these rocks are more weather resistant (Gomes, 2000), since the igneous rocks are more resistant to temperature rises.

Paragominas municipality presents ca. $61 \%\left(11,874 \mathrm{~km}^{2}\right)$ of its territory in the moderate-high attribute class (value 2.5) with sedimentary rocks of the sandstone, argillite, and silt types. This material can be composed from angular grains to sub-rounded enveloped by clay matrix of infiltration (Frostick, 1984), which can lead to greater erosive process. In $38 \%\left(7,397 \mathrm{~km}^{2}\right)$ of the municipality area there is a high vulnerability to soil erosion (value 3). These sediments have smaller interfluves (of higher-intensity dissection), for this reason receive vulnerability value higher for the geology attribute (Crepani, et al., 2001) (Fig. 5 A).

\subsubsection{Declivity attribute}

Declivity is the relief slope regarding the horizon that has a direct relation with transformation speed from potential to kinetic energy. Thus, the higher the slope the faster the potential energy of rainwater becomes kinetic energy and higher the water masses velocity and their transport capacity, responsible for relief erosion (Watson \& Laflen, 1986). With respect to this attribute, it was verified that $46 \%\left(8,954 \mathrm{~km}^{2}\right)$ of the municipality has declivity lower than $2 \%$ (value 1$)$. In $34 \%\left(6,618 \mathrm{~km}^{2}\right)$ of the municipality the slope is between $2 \%$ and $6 \%$, with low-moderate vulnerability (value 1.5). The regions presenting a slope between $6 \%$ and $20 \%$ represent $13 \%\left(2,530 \mathrm{~km}^{2}\right)$ of Paragominas, moderate vulnerability value. Lang et al., (1984) observed that zones with $9 \%$ of slope presented greater erosion between furrows of a toposoil compared to an area of $3 \%$ slope. 
Paragominas is located in the morphostructural domain of plateaus in non-folded sedimentary sequences (IBGE, 1996), characterized by flattened structural surfaces, with average altitude around $200 \mathrm{~m}$. For this reason, only $5 \%\left(973 \mathrm{~km}^{2}\right)$ of the municipality has a slope between $20 \%$ and $50 \%$ (moderate-high vulnerability), so regions having a slope higher than $50 \%$ (high vulnerability) correspond to only $2 \%\left(289 \mathrm{~km}^{2}\right)$ of the total area (Fig. 5 B).

\subsubsection{Soil attribute}

Approximately $79 \%\left(15,337 \mathrm{~km}^{2}\right)$ of Paragominas soil area are composed of latosols, which are mineral soils, deep, well-drained, with B horizon latosolic, usually cohesive, quite hard when dry, mainly in the AB and BA horizons (Rodrigues et al., 1991; Embrapa, 1999). Therefore, there are more stable soils and resistant soils to erosive processes with value 1 of vulnerability. Only $2 \%\left(389 \mathrm{~km}^{2}\right)$ of its territory has argisol soils (vulnerability value 2), since their soils are moderately stable in relation to erosive processes. This type of soil has a different textural gradient between A and B horizons, this can lead to soil loss by difficulty in infiltration, Schaefer et al., (2002), in their study identified nutrients losses by erosion on simulated rainfall conditions, with different surface coverages on argisol soils.

The vulnerable soil erosion (vulnerability value 3 ) of the municipality corresponded to the regions with Gleysol and Plintosol representing 2\% and $17 \%\left(3,698 \mathrm{~km}^{2}\right)$, respectively (Fig. 5 C). The plintosols, for example, are mineral soils formed through water percolation restriction. These soils are poorly drained with excessive plinization (Rodrigues, 2003), while gleysol is characterized by high gley status of soils, which results in a reduced moisture regime whereby soil waterlogging for a long period during the year (Embrapa, 1999).

\subsubsection{Vegetation attribute (Soil use)}

The composition and structure of the vegetation are important components in soil losses analyzes (Gomes, 2000). Deforestation is one of the anthropogenic actions that changes the forest structure and speeds up processes of soil erosion. According to the PRODES project, up to 2017 the accumulated deforestation in Paragominas reached ca. $45 \%\left(8,744 \mathrm{~km}^{2}\right)$ of its territory. These areas have been converted to others land uses, and were intended for livestock raising and crop production, mostly grain cultivation, with practices characterized by monoculture, intense mechanization and agrochemical inputs (Alves, et al., 2014). After processing the satellite imagery, $9 \%\left(1,752 \mathrm{~km}^{2}\right)$ of the municipality was identified in the high vulnerability category presenting sparse vegetation or exposed soil (Fig. 5 D)

The most stable Paragominas areas correspond to about $76 \%\left(14,793 \mathrm{~km}^{2}\right)$ of the municipality, which is occupied by ombrophilous forest with altered primary and secondary vegetation under advanced successional stage, thus, low potential for vulnerability to soil erosion. In this advanced stage of succession, there is a greater production of litter (Pezzatto \& Wisniewski, 2006; Barbosa \& Faria, 2006) that may favour soil protection, since it is the main form of nutrient return to the soil and moisture retention (Espig et al., 2009).

\subsubsection{Climate attribute}

The potential capacity of rainfall to accelerate the process of soil erosion is related to the precipitation intensity in a region (Bertoni \& Lombardi Neto, 2008; Guerra, Silva \& Botelho, 2009). The climate in humid equatorial Amazon is very favourable to the vegetal production benefiting the forest protection, acting as a huge thermostat avoiding extremes 
of temperature (Schmidt, 1947), and by means of rainfall and temperature the climate controls the weathering of a region (Mota, et al., 2009). The erosion process caused by rainfall (Santos, et al., 2010) is the result of soil particles surface disaggregation, due to the energy of the drop's impact and by the surface runoff force. The detachment and transport of sediments promotes soil losses by floods (Bertol et al., 2007; Bertoni \& Lombardi Neto, 2012).

Rainfall directly influences erosion processes, and in Paragominas the pluviometric intensity average (mm/moth) is smaller than $1 \mathrm{~mm}$ during the dry season (June to November) and more than $1,000 \mathrm{~mm}$ in the rainy season (December to May). As a consequence, the entire municipality has value $2-2.4$ moderate $\left(52 \% ; 10,044 \mathrm{~km}^{2}\right)$, to hight-moderate $2.5-2.7$ value $\left(39 \% ; 7,591 \mathrm{~km}^{2}\right)$ vulnerability to soil erosion for the climate attribute (Fig. 5 E).

Only $1.5 \%\left(311 \mathrm{~km}^{2}\right)$ of the municipality has a value of $1.7-1.9$ vulnerability considered medium-low and another $8 \%\left(1,557 \mathrm{~km}^{2}\right)$ considered to be a high vulnerability potential to soil erosion (2.8 - 3 vulnerability value). As the dry and rainy period in the municipality are well defined they do not cause a significant impact on soils covered by vegetation. The rainfall of a given region is considered a risk factor due to the production of sediments per unit of drainage area which raises with the increase of the drainage area, the larger the river basins, the greater the possibility of possible erosions (Oakes et al., 2012).

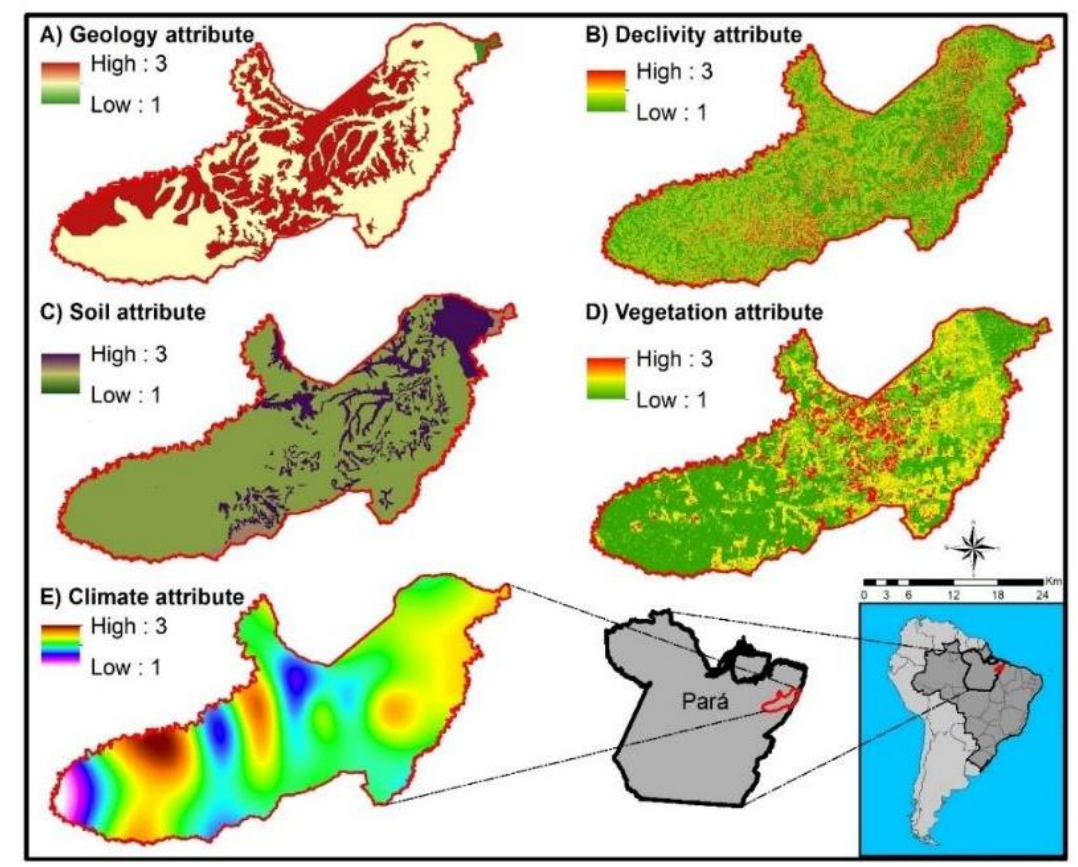

Fig. 5. Map of attributes responsible for vulnerability to soil erosion (source: authors).

\subsection{Estimation of soil loss according to (RUSLE)}

\subsubsection{Factor $\boldsymbol{R}$ (Erosivity of rains)}

Soil erosivity of this factor involves the disintegration of soil particles, transported and deposited by rainfall and surface runoff of water on the soil (Crepani, 2004). The values of 
this factor for the 28 rainfall stations vary from 5,621 to $17,540 \mathrm{MJ} . \mathrm{mm} / \mathrm{ha}$.h, with an average of 13,500 MJ.mm/ha.h, standard deviation of 1,630 MJ.mm/ha.h. Paragominas has a very heterogeneous R-factor, however, the highest and lowest values of erosivity estimation indices are found in the southeast of the municipality, which are well-vegetated zones (Fig. 6 A). According to Da Silva (2004), the highest values for the R-factor were found in the Amazon region, in that study the strong class of erosivity are between 7,000 to 9,800 MJ.mm/ha.he very strong are higher than 9800. In Paragominas only $1.7 \%$ (325 $\left.\mathrm{km}^{2}\right)$ in the strong category and $97.1 \%\left(18,892 \mathrm{~km}^{2}\right)$ in the very strong class.

\subsubsection{Factor $K$ (Soil erodibility)}

This factor is related to the soil and understanding its characteristics and properties is primordial, since its composition can affect the velocity of infiltration, water storage capacity, permeability, transport by rain, runoff, splash, dispersion and abrasion (De Lima, 2010). The soils most likely to undergo laminar erosion are in a small part of the northeast of the municipality and in the administrative limits (rivers boundaries) present in the soils Argisols $\left(2 \%, 389 \mathrm{~km}^{2}\right)$ and Gleysol $\left(2 \%, 389 \mathrm{~km}^{2}\right)$ a small part of the municipality, most of the municipality is Latosol type $\left(79 \%, 15,377 \mathrm{~km}^{2}\right)$ and has a low factor K (Fig. 6 B).

\subsubsection{Factor LS (Topographic factor)}

Considered as one of the factors of high relevance, the factor has a strong influence (Wischmeier \& Smith, 1978), because the volume of the floods is directly related to the degree of slope of the terrain, however in the municipality of Paragominas there is not a high degree of slope. Fig. $6 \mathbf{C}$ shows the distribution of the factor LS, the lowest LS value was between $0-0.029 \mathrm{th} \mathrm{Mh}^{-1} \mathrm{~mm}^{-1}$ corresponding to $8 \%\left(1,677 \mathrm{~km}^{2}\right)$ of the municipality, while the higher value that was above $9 \mathrm{t} \mathrm{h} \mathrm{Mh}^{-1} \mathrm{~mm}^{-1}$, represents only $0.03 \%\left(7 \mathrm{~km}^{2}\right)$ of Paragominas. The majority of Paragominas $\left(80 \%, 15,539 \mathrm{~km}^{2}\right)$ is between 0 to $1 \mathrm{t} \mathrm{h} \mathrm{Mh} \mathrm{Mh}^{-1}$ $\mathrm{mm}^{-1}$, with an average of $0.2 \mathrm{th} \mathrm{Mh}^{-1} \mathrm{~mm}^{-1}$ and a standard deviation of $0.9 \mathrm{t} \mathrm{h} \mathrm{Mh}^{-1} \mathrm{~mm}^{-1}$.

\subsubsection{Factor C (use/soil management) and $P$ (conservationist practices)}

Brazil loses per year tons of soil from the surface layers, which are dragged into the streams, rivers, lakes and lowlands, resulting in an increase in bed volume and a decrease in the soil covered by vegetation (Dlamini et al., 2011; Podwojewski et al., 2011). When spatializing the factor $\mathrm{CP}$ values with soil types, it was observed that the lowest values are found in the latosols, Dystrophic Argilubic Pintossol, and Gleysol soils, while the Petroferric Eutrophic have a higher $\mathrm{CP}$ value. Values range from 0 to 1 , with an average of 0.12 and a deviation of 0.21 . Paragominas has an area of $71 \%\left(13,749 \mathrm{~km}^{2}\right)$ with a CP factor between $0-0.086$, where the primary and secondary vegetation is located, between $0.087-0.047$ only $6 \%\left(1,076 \mathrm{~km}^{2}\right)$ is found in cattle ranching regions and in $24 \%(4,640$ $\mathrm{km}^{2}$ ) of Paragominas found a CP factor greater than 0.048 zones under agricultural cultivation (Fig. 6 D).

In the classification of land use and cover, the expressive classes were primary vegetation $47 \%\left(9,228 \mathrm{~km}^{2}\right)$, secondary vegetation $22,9 \%\left(4,463 \mathrm{~km}^{2}\right)$ and pasture $21,8 \%$ $\left(4,252 \mathrm{~km}^{2}\right)$ respectively, however the latter (pasture) has a higher CP value, followed by deforestation $\left(1.7 \%, 337 \mathrm{~km}^{2}\right)$ and agriculture $\left(5.6 \% 1.086 \mathrm{~km}^{2}\right)$. The data of intense agricultural production (Schlesinger, 2010) indicate that areas under crop production are increasingly overused around the world, exhausting soils capacity and making them less resilient and more vulnerable to erosion (Mazzali, 2000). 


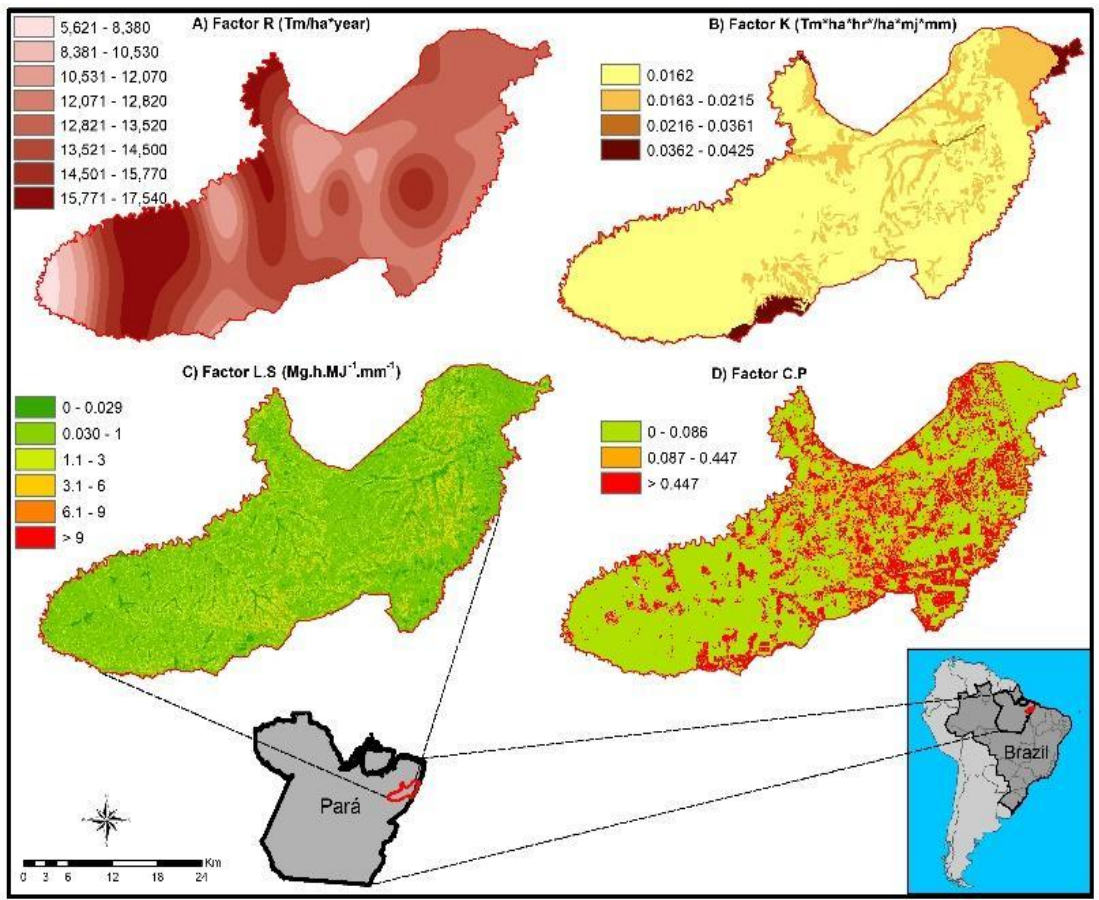

Fig. 6. Erosion estimation calculated by the RUSLE method (source: authors).

\subsection{Soil loss estimation and vulnerability (Ecodynamic concept and RUSLE method)}

These methods are widely applied in Brazil, allowing quantification and regionalization of the area with the highest risk of soil erosion. Paragominas presents ca. $77 \%\left(15,064 \mathrm{~km}^{2}\right)$ of its territory with low-moderate $\left(\mathrm{t} \mathrm{ha} \mathrm{h}^{-1}\right.$ year $\left.^{-1}\right)$ degree of soil loss calculated by the RUSLE method, not so different from the method based on the ecodynamic concept, which was $60 \%\left(11,485 \mathrm{~km}^{2}\right)$ with low and low-moderate degree of erosion of vulnerability to soil erosion (1 - 1.8 value). Similar situation was found for areas with high soil loss, with high soil loss, which represented only $3 \%\left(642 \mathrm{~km}^{2}\right)$ degree of erosion according to RUSLE and $2.7 \%\left(584 \mathrm{~km}^{2}\right)$ according to the ecodynamic concept, (Table 8, Fig. 7). This erosion can cause flow of superficial layers carrying organic matter, nutrients and seeds, resulting in high production costs (Parker et al., 1995).

In almost all variables analyzed in the two methods with respect to their potential of soil erosivity the values are similar. Soil and slope attribute, for example, obtained $79 \%$ $\left(15,377 \mathrm{~km}^{2}\right)$ and $80 \%\left(15,572 \mathrm{~km}^{2}\right)$ respectively of the municipality with low vulnerability value and erosivity estimation. Similar situation was noted for the low vulnerability degree for the vegetation attribute (soil use and cover), the result of erosivity value was $76 \%$ $\left(14,793 \mathrm{~km}^{2}\right)$ for the ecodynamic concept and $71 \%\left(13,820 \mathrm{~km}^{2}\right)$ for calculation of RUSLE (CP). The only exception was in relation to the climate and factor $\mathrm{R}$ attribute, in both methods the rainfall data are used to generate the index vulnerability and erosion estimation, only $1.5 \%\left(292 \mathrm{~km}^{2}\right)$ and $1.3\left(253 \mathrm{~km}^{2}\right)$ of Paragominas is considered as low vulnerability grade, according to the ecodynamic concept and RUSLE respectively. Consequently, for this factor, vulnerability values and erosion estimation were more significant throughout the municipality. 
Table 8.

Estimates of loss and vulnerability to soil erosion in Paragominas.

\begin{tabular}{cccc|cccc}
\hline & \multicolumn{3}{c|}{} & \multicolumn{3}{c}{ Ecodynamic model method } \\
\hline \multirow{2}{*}{$\begin{array}{c}\text { Loss of soil } \\
\left(\mathrm{t} \mathrm{ha}^{-1} \text { year }^{-1}\right)\end{array}$} & $\begin{array}{c}\text { Degree of } \\
\text { erosion }\end{array}$ & \multicolumn{2}{c}{ Municipal area } & vulnerability & \multicolumn{2}{c}{$\begin{array}{c}\text { Degree of } \\
\text { erosion }\end{array}$} & \multicolumn{2}{c}{ Municipal area } \\
\cline { 3 - 8 } & $\mathrm{Km}^{2}$ & $\%$ & values & $\mathrm{Km}^{2}$ & $\%$ \\
\hline $0-10$ & low-moderate & 15,064 & 77.4 & $1-1,5$ & low & 4,672 & 24.3 \\
\hline $10.1-50$ & moderate & 2,093 & 10.8 & $1,6-1,8$ & low-moderate & 6,813 & 35.4 \\
\hline $50.1-150$ & high-moderate & 1,665 & 8.6 & $1,9-2,1$ & moderate & 5,256 & 26.9 \\
\hline $151.1-200$ & hight & 218 & 1.1 & $2,2-2,4$ & high-moderate & 2,141 & 10.7 \\
\hline$>200$ & very high & 424 & 2.2 & $2,5-3$ & hight & 584 & 2.7 \\
\hline- & - & 19,465 & 100 & - & - & 19,465 & 100 \\
\hline
\end{tabular}

Source: Elaborated by the author.

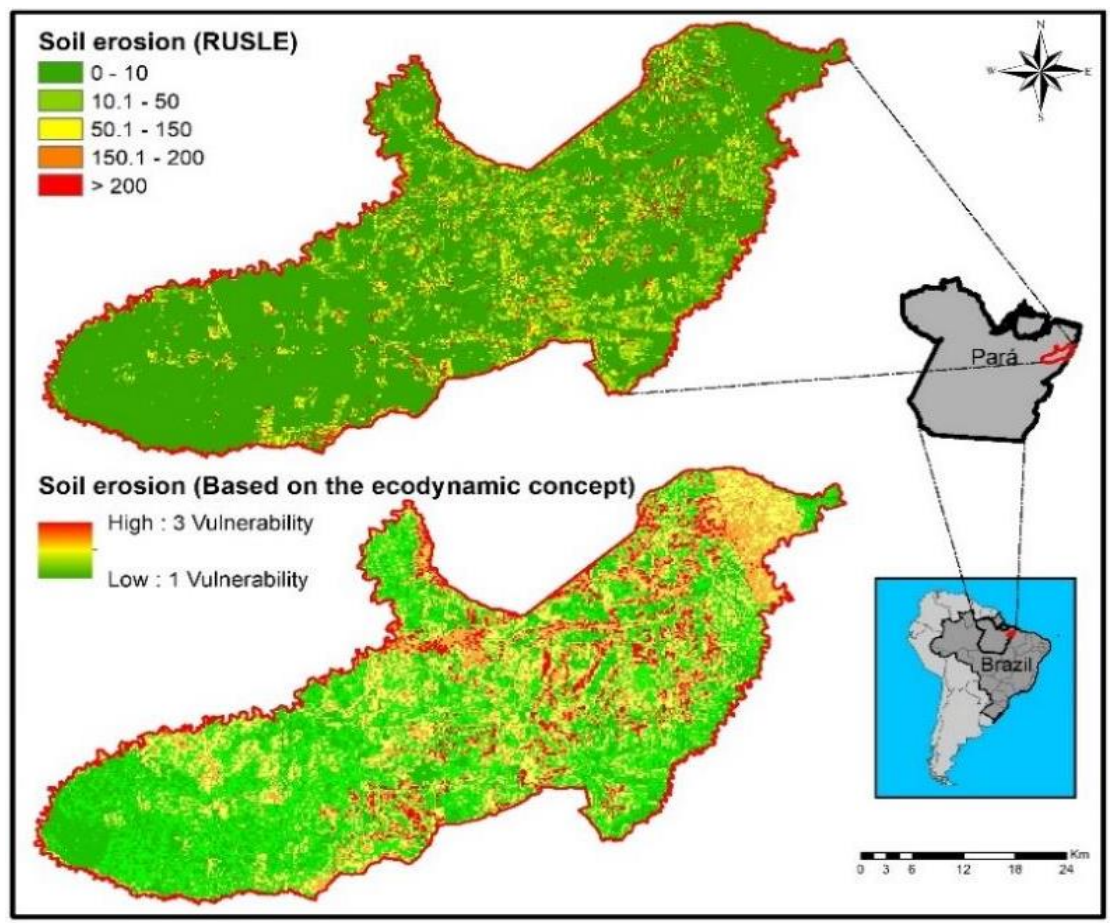

Fig. 7. Soil erosion soil calculated by the method based on the ecodynamic concept and RUSLE (source: authors).

\subsection{Management and Soil conservation}

The conservation practices aim to control soil and water losses in areas with agricultural activities, for example, without altering the productive capacity of the soil. Thus, it is important to adapt the soil conservation to the occupation of the area according to its capacity of use, so that the management practices can favor the erosion control, improving the water infiltration capacity in the soil, reducing the surface runoff that leads to the formation of aggregates and minimizing then the impact of rain drops.

The conservation processes can be mechanical, edaphic and vegetative, depending on the cropping system. However, for a good result it is necessary to apply them 
simultaneously, since each one develops a function and solves a part of the problem. The mechanical practices use artificial structures for the conduction or interception of surface runoff, while edaphic practices are related to the cropping system, controlling erosion and contributing to better soil fertility. On the other hand, the vegetative activities combat erosion based on the protection of the soil against the action of precipitation using the vegetation. For this reason, the maintenance of the adequate vegetation coverage in the soil is one of the basic principles for conservation, a process that is hampered by deforestation.

Paragominas was born in the troubled development process of the Brazilian Amazon, which was encouraged by the government in order to develop the region economically (Mahar, 1979). With around 50 years it owns already ca. $45 \%\left(8,773.3 \mathrm{~km}^{2}\right)$ from its territory deforested and converted into other uses (INPE/Prodes, 2018). Over the years these deforested areas have been converted into other uses and the municipality is currently characterized mainly by agriculture, logging and mining extraction (especially bauxite).

In the classification analyzed in this study for the period from 2004 to 2017 we noticed that between $65 \%$ and $70 \%$ of Paragominas is covered by primary vegetation altered and secondary vegetation. In the last year (2017), for example, about $47 \%\left(9,110 \mathrm{~km}^{2}\right)$ of the Paragominas territory was covered by altered primary vegetation, $23 \%\left(4,406 \mathrm{~km}^{2}\right)$ by secondary vegetation and $5.5 \%\left(1,074 \mathrm{~km}^{2}\right)$ correspond to agricultural activity (Table 9).

The values in mapped area were not so different from the agricultural areas available in the SIDRA system. However, when we analyzed the standardized agricultural production data of planted area, harvested tone and revenue, we noticed that in 2008 there was an increase in the cultivated area and in the quantity of harvested product, despite the decrease in revenue. The Worst scenario was identified in the year 2010, when crop area and revenue decreased while acreage increased. In 2012, it was the year of the best agricultural performance, according to SIDRA data, since there was a small increase in the area produced, with an increase in the area collected and a better performance of the income, during the same period the production of head of cattle was one of the worst. Another atypical event was in 2014, in that year, production and harvest decreased, but revenue grew (Fig. 8). The trend of inverse proportionality between agricultural and livestock production was also noticed, that is, when there is a decrease in livestock production, agricultural production rises, evidenced from 2008.

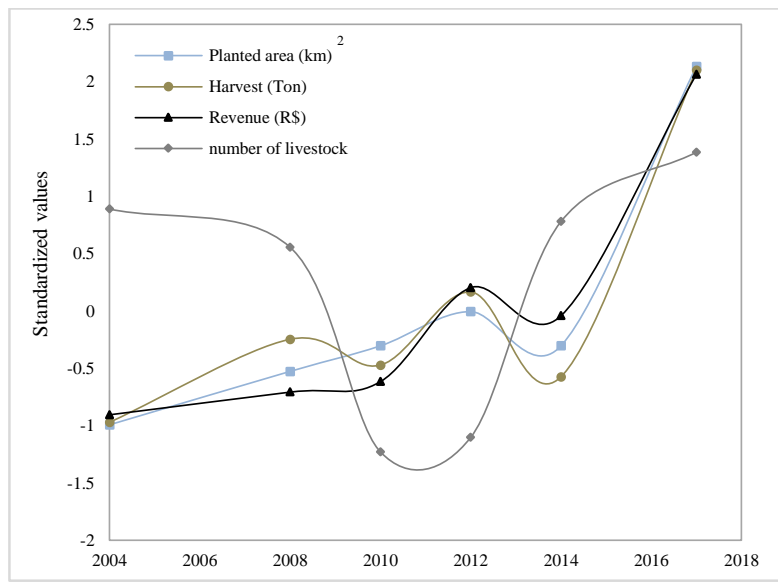

Fig. 8. Panted area, harvest and revenue of the agriculture data and number of livestock (source: authors). 
Table 9.

Land use classification (Terraclass of 2004 to 2014 and sentinel-2 of 2017)

\begin{tabular}{|c|c|c|c|c|c|c|}
\hline \multirow[t]{2}{*}{ Class } & \multicolumn{5}{|c|}{ TerraClass $\left(\mathrm{km}^{2}\right)$} & $\begin{array}{c}\text { Unsupervisionad } \\
\text { Classification }\left(\mathrm{km}^{2}\right)\end{array}$ \\
\hline & 2004 & 2008 & 2010 & 2012 & 2014 & 2017 \\
\hline Annual Agriculture & 172 & 449 & 683 & 835 & 1,019 & 1,074 \\
\hline Unobserved area & 1275 & 2,378 & 264 & 1,702 & 859 & - \\
\hline Urban area & 15 & 23 & 29 & 31 & 38 & 39 \\
\hline Deforestation & 1,029 & 55 & 64 & 16 & 10 & 333 \\
\hline Forest & 11,180 & 10,757 & 10,645 & 10,602 & 10,490 & 9,110 \\
\hline Hydrography & 26 & 50 & 50 & 50 & 26 & 45 \\
\hline Minning & - & 7 & 18 & 31 & - & 69 \\
\hline Occupation mosaic & 27 & 23 & 12 & 7 & 44 & 24 \\
\hline Non-Forest & 7 & 7 & 7 & 7 & 7 & - \\
\hline Others & 16 & 5 & 34 & 8 & 4 & 166 \\
\hline Pasture with exposed soil & - & - & 0 & 0 & - & - \\
\hline Clean pasture & 2,871 & 2,775 & 2,678 & 2,569 & 3,148 & - \\
\hline Dirty pasture & 540 & 712 & 418 & 334 & 441 & 4,199 \\
\hline Reforestation & - & - & 134 & 252 & 208 & - \\
\hline Regeneration with pasture & 707 & 224 & 1,005 & 281 & 405 & - \\
\hline Secondary vegetation & 1,601 & 2,002 & 3,423 & 2,741 & 2,767 & 4,406 \\
\hline Total & 19,465 & 19,465 & 19,465 & 19,465 & 19,465 & 19,465 \\
\hline
\end{tabular}

Source: Elaborated by the authors.

Paragominas was one of the Amazon municipalities with higher rate of illegal logging for many years. According to Imazon (Institute of Man and the Environment of the Amazon), during the period from 2007 to 2012, ca. $74 \%\left(960 \mathrm{~km}^{2}\right)$ of the municipality's logging was carried out without authorization, in all that years of monitoring the logging without permission was higher than the authorized one (Fig. 9). When analyzing the official data of wood production in $\mathrm{m} 3$ and revenue of SIDRA/PEVS - Production of Plant Extraction and Silviculture, we noticed that there is a significant difference between the production of wood in $\mathrm{m}^{3}$ in relation to the generated revenue. In the period from 2008 to 2012 the revenue increased, while the harvest decreased, that difference is quite evident when comparing the area of logging monitored by Imazon with the data of harvest and revenue in 2008, that year the logging in the municipality was $80 \%\left(601 \mathrm{~km}^{2}\right)$ of the total $\left(749 \mathrm{~km}^{2}\right)$, and the data of the PEVS also show an overestimation of the revenue in relation to production (Fig. 10), this can be explained by the illegality in the sector.

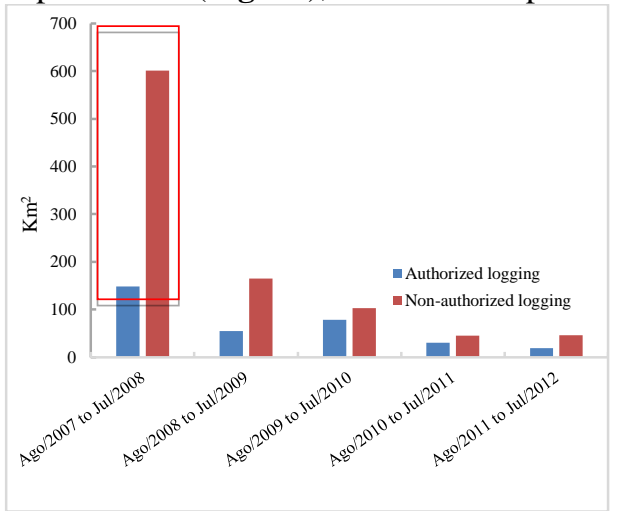

Fig. 9. Logging monitoring (Imazon).

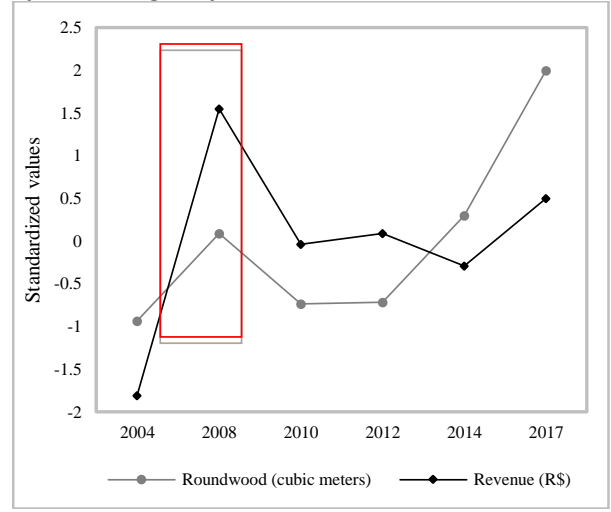

Fig. 10. Logging data (PEVS). 
Another quite significant activity mapped out in this study was mining. This activity has existed for a long time, but in the past, it did not require sophisticated technological processes. Before the areas were mined with a semi-mechanized extraction system, today they present a complex set of large equipment. One of the ores with a lot of potential in the Amazon is bauxite, which produces aluminum, which is used in various segments, such as: packaging, transportation, civil construction, electricity, consumer goods, machinery and equipment and others. It is important to point out that mining activity significantly improves the economy of a region, but also causes great degradation, since it unbalances the environment in huge extension of land and changes the soil components (Reis, 1999).

Paragominas has one of the greater enterprises of mineral activity of the state. According to DNPM (2018), the municipality presents $43 \%\left(8,308 \mathrm{~km}^{2}\right)$ of its territory under mining process, with large majority $\left(39 \%, 3,246 \mathrm{~km}^{2}\right)$ having a research permit, $27 \%$ $\left(2,318 \mathrm{~km}^{2}\right)$ with a request of mining and $25 \%\left(2,070 \mathrm{~km}^{2}\right)$ in concession (Fig. $\left.11 \mathrm{~A}\right)$. Regarding the ore class, bauxite represents ca. $72 \%\left(5,998 \mathrm{~km}^{2}\right)$ of the total in mining processes classified by DNPM (Fig. 11 B). As for the use of the extracted minerals (53\%, $4,425 \mathrm{~km}^{2}$ ) there is no information about the use, for the metallurgy activities are destined $25 \%\left(2,035 \mathrm{~km}^{2}\right)$ and about $1,726 \mathrm{~km}^{2}(21 \%)$ of area is destined for extraction of ore for industry (Fig. 11 C).

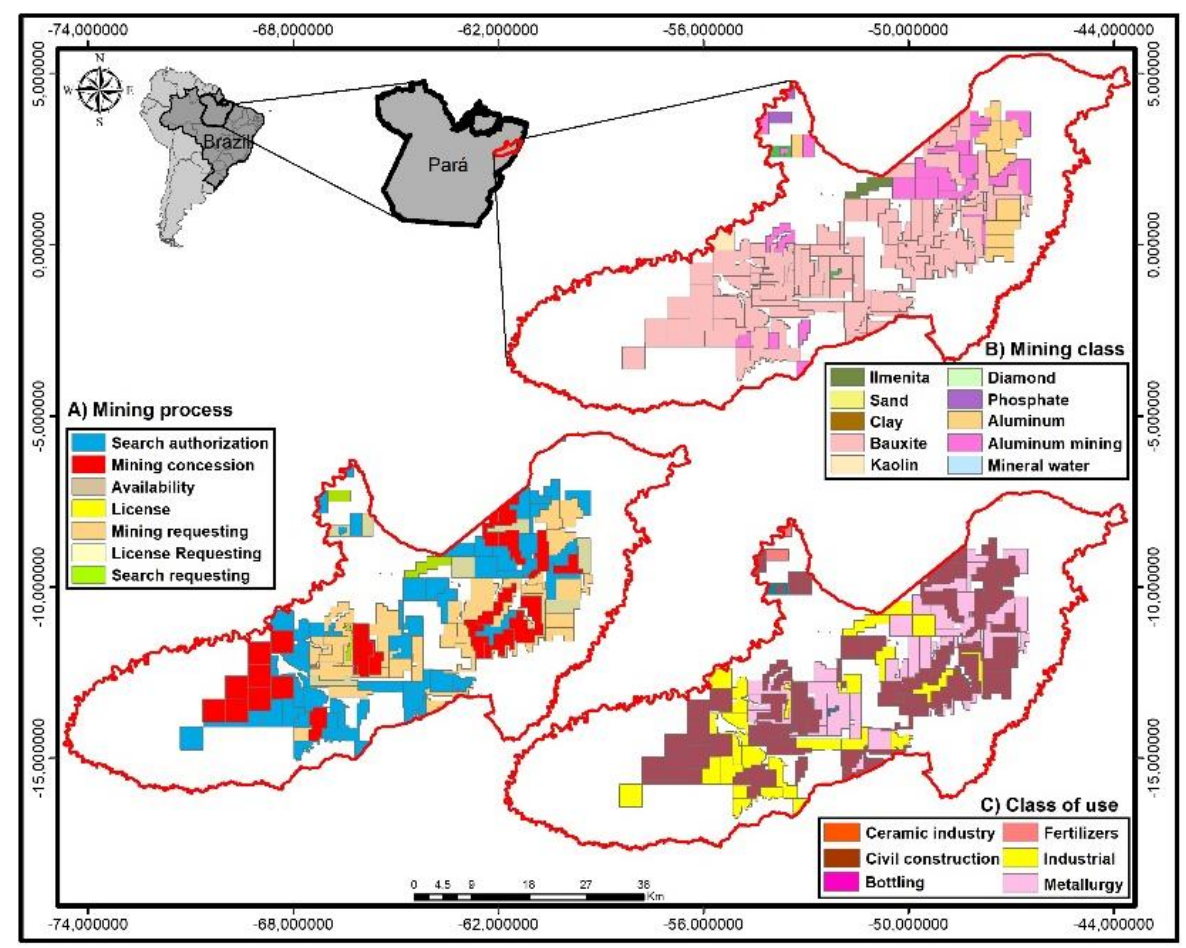

Fig. 11. DNPM mining data (source: authors). 


\section{CONCLUSION}

The attributes analyzed in the two methods presented in their majority low and intermediate vulnerability estimation and potential of soils loss, it requires attention to avoid such regions to become areas with high potential for erosion vulnerability in the future. For the two analyzed methods (Ecodynamic concept and RUSLE) only 3\% of Paragominas had a high potential of erosivity. The identification of regions with vulnerability to soil erosion potential is efficient to assist decision making and territorial management, in order to answer important environmental questions, determine low operating costs, plan activities in management practices and environmental conservation of the municipality.

Monitoring erosion over large area extensions is a costly process, so geoprocessing becomes a useful tool for estimating soil loss. The multicriteria analysis using GIS tools (Geographic Information System) were extremely important in this study, because they mapped and estimated the vulnerability potential to soil erosion for the Paragominas municipality, however there are not many studies on the subject in the Amazon region, therefore it is necessary further researches with field analysis in the region to corroborate the results. Soil erosivity is a natural process, however, inadequate human actions regarding soil use generate irreversible environmental degradation. The intense erosion process, for example, leads to soil impoverishment and pollution of water networks, causing economic, social and environmental problems on a scale from local to the global. Thus, the results of this study reveal the need for greater attention in the areas of greater environmental risk.

Good data collection and analysis of rainfall, topographic information, land cover and management system lead to significant results to be obtained from areas susceptible to degrading erosive processes. The studies associated with soil erosion are fundamental, both for agricultural conservation practices, as to subsidize the planning environmental, in which economic practices must be calculated under conservationist principles.

\section{R E F E R E N C ES}

Abel, W., Gilson Filho, M., José, R.S., José, P. And José, L.S., 2005. Determinação de Fatores da Equação Universal de Perda de Solo em Sumé, Pb. Revista Brasileira De Engenharia Agrícola e Ambiental, 9(2).

Alves, L., Carvalho, E. And Silva, L., 2014. Diagnóstico Agrícola Do Município de Paragominas, Pa. Embrapa Amazônia Oriental-Boletim de Pesquisa E Desenvolvimento (Infoteca-E).

Angima, S., Stott, D., O'neill, M., Ong, C. and Weesies, G., 2003. Soil Erosion Prediction Using Rusle For Central Kenyan Highland Conditions. Agriculture, Ecosystems \& Environment, 97(1), Pp. 295-308.

Arnesen, A.S., 2009. Análise Da Vulnerabilidade Natural à Erosão na Bacia Hidrográfica do Rio Tijucas/Sc Através de Técnicas de Geoprocessamento: Um Subsidio à Governança Territorial.

Assad, E.D. And Sano, E.E., 1998. Sistema de Informações Geográficas: Aplicações Na Agricultura.

Bakker, M.M., Govers, G., Van Doorn, A., Quetier, F., Chouvardas, D. And Rounsevell, M., 2008. The Response of Soil Erosion and Sediment Export to Land-use Change in Four Areas of Europe: The Importance of Landscape Pattern. Geomorphology, 98(3), Pp. 213-226.

Barbosa, J.H.C. And De Faria, S.M., 2006. Aporte de Serrapilheira ao Solo em Estágios Sucessionais Florestais na Reserva Biológica de Poço das Antas, Rio de Janeiro, Brasil. Rodriguésia, 461-476.

Becker, B.K., 2005. Geopolítica da Amazônia. Estudos Avançados, 19(53), Pp. 71-86.

Bertoni, J., \& Lombardi Neto, F. (2005). Conservação do solo. ícone. São Paulo.

Bertoni, J., \& Lombardi Neto, F. (2008). Conservação do solo, $7^{a}$ Edição, Editora ícone. São Paulo.

Bertoni, J.; Lombardi Neto, F. Conservação do solo. 8.ed. São Paulo: Ícone, 2012. 360p. 
Bertol, O.J., Rizzi, N.E., Bertol, I. And Roloff, G., 2007. Perdas de Solo e Água e Qualidade do Escoamento Superficial Associadas à Erosão entre Sulcos em área Cultivada sob Semeadura direta e Submetida às Adubações Mineral e Orgânica. Revista Brasileira de Ciência do Solo, $31(4)$.

Câmara, G., Moreira, F.R., Barbosa, C., Almeida Filho, R. And Bönisch, S., 2001. Técnicas de Inferência Geográfica. Câmara, G.; Davis, C.; Monteiro, Amv; Paiva, Ja.

Cerdan, O., Govers, G., Le Bissonnais, Y., Van Oost, K., Poesen, J., Saby, N., ... \& Klik, A. (2010). Rates and spatial variations of soil erosion in Europe: a study based on erosion plot data. Geomorphology, 122(1-2), 167-177.

Crepani, E., Medeiros, J.D., Hernandez Filho, P., Florenzano, T.G., Duarte, V. And Barbosa, C.C.F., 2001. Sensoriamento Remoto e Geoprocessamento Aplicados ao Zoneamento EcológicoEconômico e ao Ordenamento Territorial. Inpe São José dos Campos.

Crepani, E., Medeiros, J. D., \& Palmeira, A. F. (2004). Intensidade pluviométrica: uma maneira de tratar dados pluviométricos para análise da vulnerabilidade de paisagens à perda de solo. São José dos Campos: INPE.

Chaplot, V., Giboire, G., Marchand, P., \& Valentin, C. (2005). Dynamic modelling for linear erosion initiation and development under climate and land-use changes in northern Laos. Catena, 63(23), 318-328.

Da Silva, A. M. (2004). Rainfall erosivity map for Brazil. Catena, 57(3), 251-259.

Da Silva Barros, P. P., Fiorio, P. R., Martins, J. A., \& Demattê, J. A. M. (2016). Comparação entre o uso e ocupação e perda de solo, nos anos de 1995 e 2010, na microbacia hidrográfica do Ceveiro. Revista Ambiência, v. 12, n. 2, p. 513-523.

De Lima, E. R. V. (2010). Erosão do solo: fatores condicionantes e modelagem matemática. CADERNOS DO LOGEPA, 3(1).

Dlamini, P., Orchard, C., Jewitt, G., Lorentz, S., Titshall, L., \& Chaplot, V. (2011). Controlling factors of sheet erosion under degraded grasslands in the sloping lands of KwaZulu-Natal, South Africa. Agricultural Water Management, 98(11), 1711-1718.

Embrapa, 1999. Centro Nacional De Pesquisas de Solos. Sistema Brasileiro de Classificação de Solos. Rio de Janeiro: Embrapa/Solos, 412p.

Espig, S.A., Freire, F.J., Marangon, L.C., Ferreira, R.L.C., Freire, Maria Betânia Galvâo dos Santos and Espig, D.B., 2009. Sazonalidade, Composição e Aporte de Nutrientes da Serapilheira em Fragmento de Mata Atlântica. São José dos Campos: Scielo Brasil.

ESRI, A. (2012). ArcGIS 10.1. Environmental Systems Research Institute, Redlands, CA.

Fao - Food and Agriculture Organization of the United Nations. Statistical Databases. Agriculture2017.

Ferreira, L.G., Ferreira, N.C. and Ferreira, M.E., 2008. Sensoriamento Remoto da Vegetação: Evolução E Estado-Da-Arte. Acta Scientiarum.Biological Sciences, 30(4).

Fiorio, P. R., da Silva Barros, P. P., de Oliveira, J. S., \& Nanni, M. R. (2016). Estimativas de perda de solo em ambiente SIG utilizando diferentes fontes de dados topográficos Estimates of soil loss in a GIS environment using different sources of topographic data. AMBIÊECIA, 12(1), 203-216.

Frostick, L. E., Lucas, P. M., \& Reid, I. (1984). The infiltration of fine matrices into coarse-grained alluvial sediments and its implications for stratigraphical interpretation. Journal of the Geological Society, 141(6), 955-965.

Gomes, A.R., 2000. Avaliação Da Vulnerabilidade À Perda De Solo Em Região Semiárida Utilizando Sensoriamento Remoto E Geoprocessamento-Área Piloto De Parnamirim-Pe, Inpe - Instituto Nacional De Pesquisas Espaciais.

Guerra, A. T., da Silva, A. S., \& Botelho, R. G. M. (2009). Erosão e conservação dos solos: conceitos, temas e aplicações. Bertrand Brasil.

Hall, A.L., 1989. Developing Amazonia: Deforestation and Social Conflict in Brazil's Carajás Programme. Manchester University Press.

Ibge - Instituto Brasileiro De Geografia E Estatística, 1996. Mapa Geomorfológico das Folhas Sa. $23 v-A$ E Sa $23 \mathrm{~V}$-C. 
Inpe - Instituto Nacional de Pesquisas Espaciais. Projeto Prodes - Monitoramento da Floresta Amazônica Brasileira por Satélite. Disponível em: <http://www.obt.inpe.br/prodes/index.html>. Acessado em: 30/09/2018.

Kohlhepp, G., 2002. Conflitos De Interesse no Ordenamento Territorial da Amazônia Brasileira. Estudos Avançados, 16(45), Pp. 37-61.

Lang, K.J., Prunty, L., Schroeder, S. And Disrud, L., 1984. Interrill Erosion as an Index of Mined Land Soil Erodibility. Transactions of The Asae, 27(1), Pp. 99-0104.

Lal, R. (2017). Soil erosion by wind and water: problems and prospects. In Soil erosion research methods (pp. 1-10). Routledge.

Lepsch, I. F. (2016). Formação e conservação dos solos. Oficina de textos.

Mahar, D.J. 1979. Frontier development policy in Brazil: a study of Amazonia. Praeger, Nova York

Mazzali, L., 2000. O Processo Recente De Reorganização Agroindustrial: Do Complexo À Organização" Em Rede". Unesp.

Mota, G. V., Vitorino, M. I., Cunha, A. C. D., Kuhn, P. A. F., Ferreira, D. B. D. S., Santos, D. M., ... \& Souza, J. R. S. D. (2009). Precipitação sazonal sobre a Amazônia oriental no período chuvoso: observações e simulações regionais com o RegCM3.

Navas, A., Machín, J. And Soto, J., 2005. Assessing Soil Erosion in a Pyrenean Mountain Catchment Using Gis And Fallout 137 Cs. Agriculture, Ecosystems \& Environment, 105(3), Pp. 493-506.

Oakes, E. G. M., Hughes, J. C., Jewitt, G. P. W., Lorentz, S. A., \& Chaplot, V. (2012). Controls on a scale explicit analysis of sheet erosion. Earth Surface Processes and Landforms, 37(8), 847-854.

Parker, D.B., Michel, T.G. And Smith, J.L., 1995. Compaction and Water Velocity Effects on Soil Erosion in Shallow Flow. Journal of Irrigation and Drainage Engineering, 121(2), Pp. 170-178.

Pezzatto, A.W. And Wisniewski, C., 2006. Produção de Serapilheira Em Diferentes Seres Sucessionais da Floresta Estacional Semidecidual No Oeste Do Paraná. Floresta, 36(1).

Podwojewski, P., Janeau, J. L., Grellier, S., Valentin, C., Lorentz, S., \& Chaplot, V. (2011). Influence of grass soil cover on water runoff and soil detachment under rainfall simulation in a sub-humid South African degraded rangeland. Earth Surface Processes and Landforms, 36(7), 911-922.

Prado, H. Solos do Brasil. 2.ed. Piracicaba: H. Prado, 2001. 220p.

Rodrigues, T.E., Junior, Oliveira. R. C De, Silva, J. M. L Da, Valente, M.A. and Capeche, C.L., 1991. Caracterizaçâo Físico-Hídrica Dos Principais Solos Da Amazônia Legal.

Rodrigues, T. E., Silva, R. D. C., Da Silva, J. M. L., De Oliveira Junior, R. C., Gama, J. D. F., \& Valente, M. A. (2003). Caracterização e classificação dos solos do município de Paragominas, Estado do Pará. Embrapa Amazônia Oriental-Documentos (INFOTECA-E).

Santos, G. G., Griebeler, N. P., \& Oliveira, L. F. C. D. (2010). Chuvas intensas relacionadas à erosão hídrica.

Schaefer, C.E.R., Silva, D.D., Paiva, K.W.N., Pruski, F.F., Albuquerque Filho, M.R. and Albuquerque, M.A., 2002. Perdas de Solo, Nutrientes, Matéria Orgânica e Efeitos Microestruturais Em Argissolo Vermelho-Amarelo Sob Chuva Simulada. Pesquisa Agropecuária Brasileira, 37(5), Pp. 669-678.

Schlesinger, S. (2010). Onde pastar?: o gado bovino no Brasil. Rio de Janeiro: Fase.

Schmidt, J. C. J. (1947). O clima da Amazônia. Instituto brasileiro de geografia e estatistica.

Serra, M.A., 1998. The Social Impacts of Regional Development Policies In Eastern Amazonia: A Case Study Of Parauapebas, London School of Economics and Political Science.

Tricart, J., 1977. Ecodinâmica. Série Recursos Naturais E Meio Ambiente. Supren/Ibge.

Verheijen, F. G., Jones, R. J., Rickson, R. J., \& Smith, C. J. (2009). Tolerable versus actual soil erosion rates in Europe. Earth-Science Reviews, 94(1-4), 23-38.

Watrin, O.D.S. And Da Rocha, A., 1992. Levantamento Da Vegetação Natural E Do Uso da Terra No Município De Paragominas (Pa) Utilizando Imagens Tm/Landsat. Embrapa Amazônia OrientalSéries Anteriores (Infoteca-E).

Watson, D. And Laflen, J., 1986. Soil Strength, Slope, And Rainfall Intensity Effects on Interrill Erosion. Transactions of The Asae, 29(1), Pp. 98-0102.

Wischmeier, W. H., \& Smith, D. D. (1978). Predicting rainfall erosion losses-a guide to conservation planning. Predicting rainfall erosion losses-a guide to conservation planning. USDA, $62 \mathrm{pp}$. 